\title{
An Assessment of Environmental Pollution by Some Trace Metals in the Northern Part of Shatt Al-Arab Sediments, Southern Iraq
}

\author{
Faiq A. Al-Manssory \\ Department of Marine Geology \\ Marine Science Center \\ Basrah University
}

\author{
Mohammed A. Abdul Kareem \\ Department of Soil and Water Sciences \\ College of Agriculture \\ Basrah University
}

\author{
Mohammed M. Yassen \\ Department of Soil and Water Sciences \\ College of Agriculture \\ Basrah University
}

(Received 13/6/2002 ; Accepted 18/1/2003)

\begin{abstract}
The concentration of five trace metals $\mathrm{Cd}, \mathrm{Cu}, \mathrm{Ni}, \mathrm{Pb}$ and $\mathrm{Zn}$ wrer determined in the surface sediments of five stations along $17 \mathrm{~km}$ of northern part of Shatt Al-Arab River during 1997-1998.

The range of exchangeable trace metals concentrations $\left(\mu g^{-1}\right.$ d.w.) were as following: $\mathrm{Cd}$ (4.98-32.80), $\mathrm{Cu}$ (19.38-39.22), $\mathrm{Ni}$ (79.46-326.38), $\mathrm{Pb}$ (59.00-114.19) and $\mathrm{Zn}$ (111.07-131.79). Accordingly, the study area environment is heavily polluted by $\mathrm{Cd}$, $\mathrm{Ni}$ and $\mathrm{Pb}$, and moderately by $\mathrm{Cu}$ and $\mathrm{Zn}$. The northern part of the study area seems to be a source point for pollution by $\mathrm{Cd}$ indicating an industrial pullution at the area. While the pollution by $\mathrm{Ni}$ reflecting a clear image of hydrocarbon substance contamination, however, the pollution sources of $\mathrm{Pb}$ are Basrah port, Ashar channel and Al-Naser oil jetties in Abu Al-Khassib town because these stations have received a sewage effluent indicating anthropogenic pollution for the river ecosystem. The eastern part of Khorah station was found polluted by $\mathrm{Cu}$ whereas Dockyard and Ashar channels were polluted by $\mathrm{Zn}$ metal.

On the temporal basis, the study area reflects a climbing rate of pollution, especially after the aggression on Iraq.
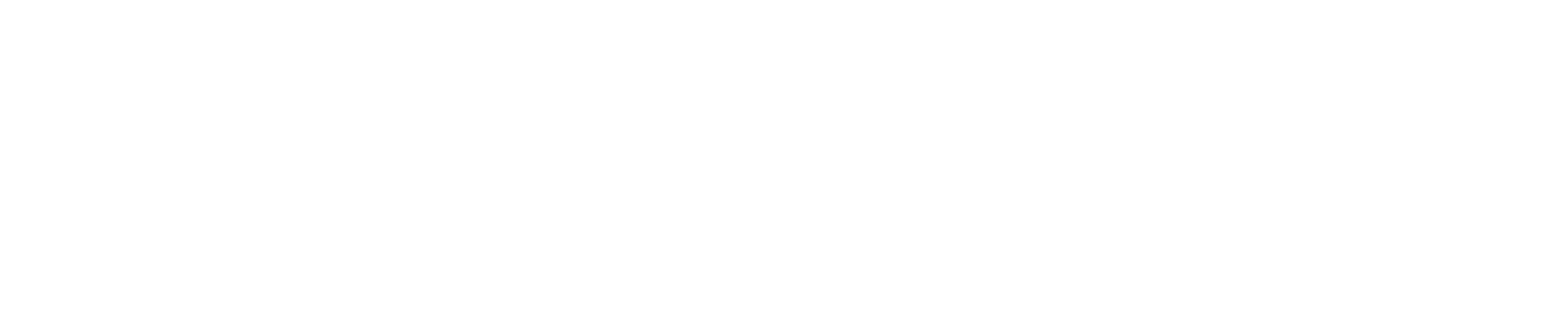

مَ قيلس خمسة عناصرمن العناصر الزرة (Zn,Pb, Ni, Cu, Cd) في رولمب خطسة مهط لت تمتد على مسافة 17 كيلومترامن الجزء للثمالي منشط العرب خلل الفترة 1997-1998.
\end{abstract}


وكلن مدى تركيز الطور المتبال لهذه العناصر مقلسا بـ ـ (ميكروغراd/غم وزن جلف) كما يل مي:

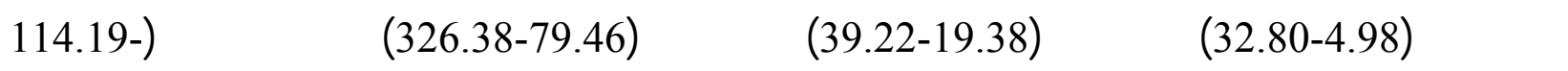

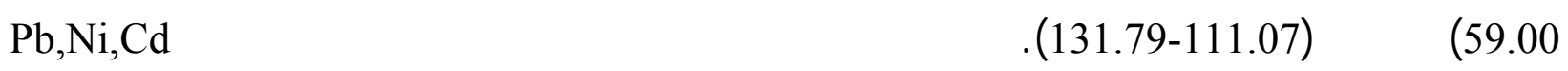

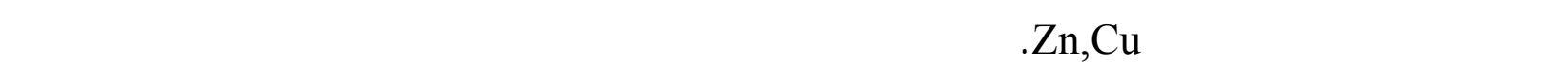

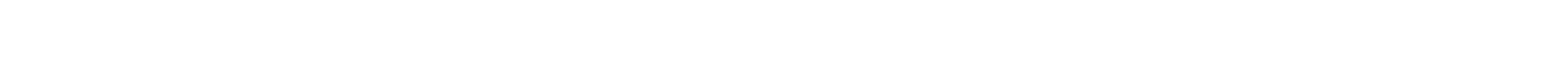

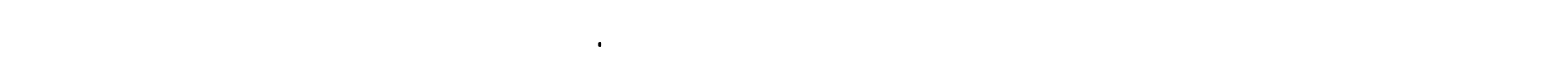

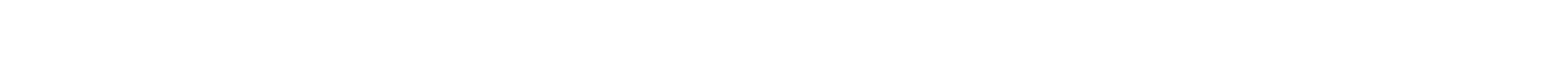

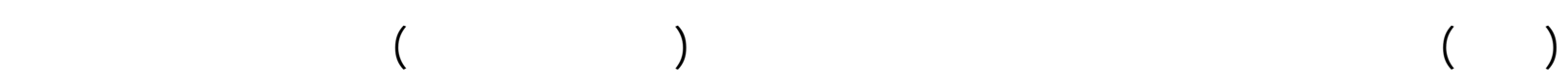

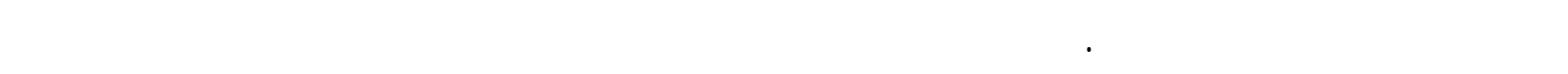
وكذلك مطقة الدلكير وقنة العشار.

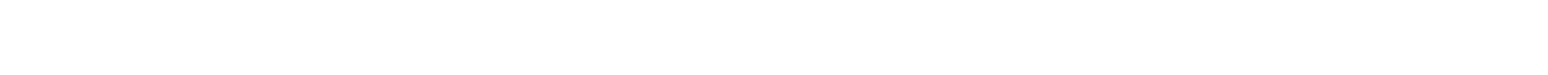
العدوان الثلاثيني على العراق.

\section{INTRODUCTION}

Trace metal pollution can affect many areas of the world in the developed and developing countries. Pollution of fluvial and coastal marine environments by these metals is being major of concern since may lead to deterioration of natural habits or also cause a serious public health hazard (Anderlini et al., 1986). Trace components in the environment are continuously redistributed in hydrological, hydrochemical as well as biological cycles and pathways (Ledin et al., 1989). The distribution and concentration levels of trace metals have, however, changed drastically during the last decades due to human activities.

Analysis of sediments being a useful method of study environment pollution of trace metals and has been used in numerous investigation in fluvial or marine environments (Johansson, 1989). Only absorbed metals on the sediments and associated with carbonate and organic material are of interest to pollution studies (Anderlini et al., 1982).

There are many studies focusing on this topic at Satt Al-Arab Estuary and the coastal and near by marine environment. Al-Hashimi and Salman (1985) established background levels of the trace metals in the sediments of Shatt Al-Arab Estuary and the NW coast of the Arabian Gulf. Abaychi and Dou Abul (1986) studied the geochemical fractionation of $\mathrm{Cd}, \mathrm{Cr}, \mathrm{Cu}, \mathrm{Fe}, \mathrm{Mn}, \mathrm{Ni}, \mathrm{Pb}, \mathrm{V}$ and $\mathrm{Zn}$ in the surfacial sediment from the same area and Khor Al-Zubair. Al-Mussawy and Salman (1989) investigated Co, Cu, Fe, $\mathrm{Mn}, \mathrm{Ni}, \mathrm{V}$ and $\mathrm{Zn}$ in the surfacial marine sediment of Khor A-Zubair.

There are many studies on these metals in the fluvial and lacustrain environments. Saleh (1982) gave a high record of $\mathrm{Cd}, \mathrm{Ni}, \mathrm{Pb}$ and the moderate one of $\mathrm{Cu}$ and $\mathrm{Zn}$ at Azair and Qurna. Abaychi and Dou Abul (1985) study Cd, Co, Cr, Cu, Fe, Mn, Ni, Pb, V and $\mathrm{Zn}$ in the northern part of Shatt Al-Arab River. From other view point, Abaychi and Mustafa (1988) uses the Asiatic clam as a bio-indicator of trace metal pollution in Shatt 
Al-Arab River. They gave a highest record of $\mathrm{Cd}$ and $\mathrm{Cu}$ of exchangaeble particulate metals form and moderate value of $\mathrm{Zn}$ near Basrah City. There are no such investigations on the lacustrain environment except the study of Al-Dabbas and Hassan (1992). While Mustafa and Al-Saad (1995) concluded that aquatic vascular plants are useful indicator organisms for pollution monitoring studies at this environment.

At Shatt Al-Arab River and its estuary, Al-Khafaji et al. (1997) studied concentration of $\mathrm{Cd}, \mathrm{Cu}, \mathrm{Ni}, \mathrm{Pb}$ and $\mathrm{Zn}$ at two stations in Shatt Al-Arab Estuary in dissolved and particulate phases. Al-Imarah and Al-Khafaji (1998) try to investigate the effect of industrial effluent upon Shatt Al-Arab River water and sediment at three stations in sahatt Al-Arab River.

Al-Hejuje (1999) determines $\mathrm{Co}, \mathrm{Ni}, \mathrm{Mn}$ and $\mathrm{Fe}$ in Ashar and Al-Khandk (Dockyard) channels considered (at this time) as a sewage canals influx their polluted materials to the river body. Meanwhile, at the same period of this work 1997-1998 (Al-Imarah, 2001) determine the concentration levels of $\mathrm{Cd}, \mathrm{Cr}, \mathrm{Ni}, \mathrm{Pb}$ and $\mathrm{Zn}$ of dissolved and particulate phases of Shatt Al-Arab River water.

The aims of this study are to evaluate the possible source of pollution at the study area, and the possible effect of deposition of these metals to the river eosystem.

\section{Study area:}

Shatt Al-Arab River is formed by the influence of Tigris and Euphrates Rivers at Qurna City about $90 \mathrm{Km}$ northern of Basrah City. It drains into Arabian Gulf with total length of about $195 \mathrm{Km}$ (Fig.1). The sources of sediment in the northern part of the river are from many origins with different proportion (Albadran and Al-Manssory, 1999).

The water of the river considers as an important resource for rural, urban and industrial activities. It is also being as a main waterway between the human residence at both sides. Shatt Al-Arab River water is liable to small oil spills of varying magnitudes, the major source for the input of petroleum substances are Maftiah oil-terminal and AbuFlous (Al-Naser) oil jetties. Another important source of pollution for the river ecosystem is sewage discharge by tidal channel across Basrah City that connected with the river.

\section{Field works:}

\section{MATERIALS AND METHODS}

Sampling work was achieved at three sites (east, west and mid-channel) of five stations along $17 \mathrm{Km}$ of the northern segment of Shatt Al-Arab River (Fig.1). These stations were chosen to take surfacial sediment sample to reflect urban and rural activities. Surface sediments were taken by stainless steel Van Veen grab sampler, and only the top few centimeters in the middle of the sample were taken by means of plastic scope. Sampling was carried out during July-August 1997 and January-February 1998. 
Faiq A. Al-Manssory et al.

Fig.1: Map of Shatt Al-Arab River and position of the samples stations. 


\section{Laboratory methods:}

Sediments samples were prepared for metal analysis by leaching air dried samples, with $50 \% \mathrm{HNO}_{3}$ for two hours at $90-95{ }^{\circ} \mathrm{C}$. After leaching, the samples were centrifuged for 20 min., rinsed with de-ionized water and supernatant decanted into $25 \mathrm{ml}$ volumetric flasks. This step was repeated twice, and the samples were stored in capped p;astic bottles for later analysis by PYE Unicam flame atomic absorption spectrophotometer (AAS) type Sp9 (Anderlini et al., 1982), in soil and water department laboratories. A subsample was taken to determine grain size distribution according to Folk (1974). Mean grain-size in phi units $(\mathrm{MZ} \varphi)$ of the samples was calculated according to Folk and Ward (1957).

Aliquot of samples were taken to determine calcium carbonate percentage $\left(\mathrm{CaCO}_{3} \%\right)$ by adding $1 \mathrm{~N} \mathrm{HCl}$ acid and back titration with $1 \mathrm{~N} \mathrm{NaOH}$ using phenoliphthaline indicator (Jackson, 1958). Total organic carbon percentage (TOC\%) was determined following the procedure proposed by Welkly and Black, which mentioned at Pabe et al. (1982). All samples were ruined by two replicates.

\section{Evaluation of spatial variations:}

\section{RESULTS AND DISCUSSION}

Knowledge of the concentrations and distribution of trace metals in sediment can play a key role in detecting sources of pollution in aquatic systems (Forstner and Wittman, 1979). The distribution of $\mathrm{Cd}, \mathrm{Cu}, \mathrm{Ni}, \mathrm{Pb}$ and $\mathrm{Zn}$ in the study area, (fig.2) shows that the northern part of the study area is a source point of pollution with cadmium (32.80 $\mathrm{\mu gg}^{-1}$ d.w.) (Table 1). The probable sources of this metal are from petrochemical pigments, fertilizers and petroleum refining (Dean et al., 1972). A further important source is atmospheric emission, which contain cadmiuim from melting scraps (Forstner and Muller, 1973). Basrah port in Maqqal station and Muftiah oil-terminal (formerly petroleum refinery) considered as a possible source for this element to Shatt Al-Arab ecosystem.

Table 1: Average values of exchangeable trace metals $\left(\mu g^{-1}\right.$ d.w.) and sedimentological parameters of Shatt Al-Arab River sediment.

\begin{tabular}{|l|c|c|c|c|c|c|}
\hline \multirow{2}{*}{ Parameters } & Stations & $\mathbf{1}$ & $\mathbf{2}$ & $\mathbf{3}$ & $\mathbf{4}$ & $\mathbf{5}$ \\
\cline { 3 - 7 } & $\mathrm{Cd}$ & 32.80 & 11.25 & 5.78 & 6.84 & 4.98 \\
\hline \multirow{4}{*}{$\begin{array}{l}\text { Trace metal concentrations } \\
\left(\mu \mathrm{gg}^{-1} \text { d.w. }\right)\end{array}$} & $\mathrm{Cu}$ & 38.44 & 23.75 & 39.22 & 29.81 & 19.38 \\
\cline { 2 - 7 } & $\mathrm{Ni}$ & 182.66 & 326.38 & 79.46 & 122.77 & 256.11 \\
\cline { 2 - 7 } & $\mathrm{Pb}$ & 79.27 & 68.89 & 114.19 & 59.00 & 80.98 \\
\cline { 2 - 7 } & $\mathrm{Zn}$ & 127.18 & 111.07 & 131.79 & 125.28 & 123.39 \\
\hline \multirow{3}{*}{$\begin{array}{l}\text { Sedimentological } \\
\text { parameters }\end{array}$} & $\mathrm{Mz}(\varphi)$ & 8.88 & 9.74 & 7.25 & 9.56 & 8.73 \\
\cline { 2 - 7 } & $\mathrm{Clay} \%$ & 54.85 & 62.05 & 45.56 & 61.81 & 56.81 \\
\cline { 2 - 7 } & $\mathrm{TOC}_{0}$ & 0.88 & 1.11 & 1.25 & 1.03 & 1.09 \\
\cline { 2 - 7 } & $\mathrm{CaCO}_{3} \%$ & 27.28 & 28.16 & 24.13 & 29.97 & 30.57 \\
\hline
\end{tabular}


Faiq A. Al-Manssory et al.

Fig.2: The distribution of exchangeable trace metals $\left(\mu g^{-1}\right.$ d.w.) in the surface sediment of Shatt al-Arab River. Where the top of each column is East side of the river, while the bottom is the West side. 
Contouring pattern of Copper shows a high concentration around the outflow of Salehiah creek at the east side of Shatt Al-Arab River near Khorah station (Fig.1). The highest values were recorded at Ashar station (39.22 $\mu \mathrm{gg}^{-1}$ d.w.) (Table 1). The possible source of this metal could be from agricultural activities in this area, since fertilizers as one of its sources to the aquatic environment (Dean et al., 1972). Another source may be from corrosion of artillery bombshells and machine gun bullets during the first Gulf war since nearby area being battlefield for many years.

Figure (3) also exhibits Nickel distribution in the surfacial sediment of northern part of Shatt Al-Arab River, which shows the highest concentration among the other studied metals along the study area. The higher average value $\left(326.38 \mu \mathrm{gg}^{-1}\right.$ d.w.) was recorded at Silo station (Table 1), which is located near Muftiah oil terminal. The abundance of nickel in the river sediment may be related to the petroleum rich substrate (Abaychi and Dou Abal, 1985). Since while field observations show that the water surface of Shatt AlArab River seem like a mirror at a day light during summer months, this because of oil spills that coming from Muftiah oil terminal. Another peak of this metal was found at Muhellah station (near Abu Al-Khassib) (Fig.3) which recorded (256.11 $\mu \mathrm{gg}^{-1}$ d.w.) (Table 1). This station is located near Al-Naser oil-jetties.

The maximum concentration of lead metal $(\mathrm{Pb})$ was recorded at station 1,3 , and 5 (79.27, 114.19 and $80.98 \mu \mathrm{gg}^{-1}$ d.w.) respectively (Table 1 ). These stations have received a sewage effluent and permit a busy vehicle movement. Since the traffic movement considered as a main source of aquatic environment pollution with lead compounds, this material reaches the environment by air dust or sewage effluent (AbdulRaheem et al., 1987. Ashar station has recorded the highest value of $\mathrm{Pb}$ concentration through the study area because of its possess the highest level of TOC\% (1.25\%) (Table 1).

Zinc concentration is relatively equally also along the study area. Ashar station recorded the highest value (131.79 $\mu^{-1} g^{-1}$ d.w.) (Table 1) because it possesses the highest level of TOC \%, due to relationship between zinc concentration and high levels of detritus (Radwan et al., 1990).

\section{Evaluation of temporal variations:}

Values of exchangeable trace metal concentrations of Abaychi and Dou Abal (1985) at the northern part of Shatt Al-Arab River between Qurna and Basrah City, is consider as a background level for this study in order to clarify the temporal variations. Figure (3) summarizes the results of this study and shows clearly that there is a large-scale contamination with all of the studied metals, especially for cadmium and zinc (Table 2).

This study is compared with the former studies at Shatt Al-Arab River, its estuary and the northern part of Arabian Gulf. Only the studies that use Unicam AAS type Sp9 exclusively were put under comparison while the other that didn't use this type of AAS were excluded. The trace metal concentration in the NW Arabian Gulf and Kuwaiti marine environment during mid-eighteen of the $20^{\text {th }}$ Century were shown in Table (2). For Shatt Al-Arab Estuary, Al-Khafaji et al. (1997) and Al-Imarah et al. (1998) represent the latest studies upon this topic during the end of nineties of the last century. Second study gave lower values for the studied metals concentration at the same time and space, except of nickel (Table 2). But it still higher the background levels that given by Al-Hashimi and Salman (1985). 
Faiq A. Al-Manssory et al.

Fig.3: Differences of exchangeable trace metal concentrations ( $\mu \mathrm{gg}^{-1}$ d.w.) of Shatt Al-Arab River sediment, plotted over a general background (shaded strips). The vertical lines represent mean standard error of the samples. 
Table 2: Mean concentration of exchangeable trace metal $\left(\mu g^{-1}\right.$ d.w.) of the NW Arabian Gulf and Shatt Al-Arab River sediments.

\begin{tabular}{|c|c|c|c|c|c|c|c|}
\hline \multirow{2}{*}{\multicolumn{2}{|c|}{ Location }} & \multicolumn{5}{|c|}{ Trace metal conc. $\left(\mu g^{-1}\right.$ d.w.) } & \multirow{2}{*}{ References } \\
\hline & & Cd & $\mathbf{C u}$ & $\mathbf{N i}$ & $\mathbf{P b}$ & Zn & \\
\hline \multirow{2}{*}{$\begin{array}{l}\text { NW Arabian } \\
\text { Gulf }\end{array}$} & Arabian Gulf & 0.17 & 7.00 & 91.00 & 5.00 & 3.40 & Abaychi and Dou Abul (1986) \\
\hline & Kuwaiti Marine Env. & 1.40 & 23.00 & 91.00 & 27.00 & 57.00 & Anderlini et al. (1986) \\
\hline \multirow{7}{*}{$\begin{array}{l}\text { Shatt Al-Arab } \\
\text { River }\end{array}$} & Azair-Qurna & 6.00 & 33.75 & 284.00 & 87.50 & 76.00 & Saleh (1982) \\
\hline & Qurna-Basrah & 0.15 & 11.90 & 42.00 & 12.20 & 6.0 & Abaychi and Dou Abul (1985) \\
\hline & Qurna-Abu Al-Khassib & 51.65 & 216.63 & 13.60 & 5.43 & 108.85 & Abaychi and Mustafa (1988) \\
\hline & Fao-Ras Al-Bisha & 0.20 & 13.85 & 25.80 & 17.05 & 8.00 & Al-Khafaji et al. (1997) \\
\hline & Deer-Hartha & 10.40 & 6.66 & 42.40 & 25.17 & 24.70 & Al-Imarah and Al-Khafaji (1998) \\
\hline & Fao-Ras Al-Bisha & 0.18 & 9.19 & 16.15 & 12.92 & 5.81 & Al-Imarah et al. (1998) \\
\hline & Maqqal-Muhellah & 12.26 & 30.12 & 189.39 & 80.47 & 125.09 & Present study \\
\hline
\end{tabular}

Whereas Abaychi and Mustafa (1988) gave the highest levels of $\mathrm{Cd}$ and $\mathrm{Cu}$, even though higher than this study. But it gives a nearby estimation of zinc metal of our study (Table 2), On close sight of Table (2), we could see that the studied trace metals concentration were going to rise in climbing rate especially after the aggression on Iraq. Figure (3) also exhibits a large-scale concentration of $\mathrm{Cd}, \mathrm{Cu}$ and $\mathrm{Pb}$ metals of anthropogenic origin in the northern part of the study area.

\section{The assessment of environmental ecosystem:}

Results show that there is a real difference between the metals under consideration through the study area because of high values of standard deviation and a high coefficient of variation, especially for $\mathrm{Cd}, \mathrm{Ni}$ and $\mathrm{Pb}$ (Table 3 ).

Since electroplanting works may increase the concentrations of cadmium in nearby sediment by over one hundred times (Warren, 1981), and because of Maqqal station is located relatively close to two major power plants in Basrah City, it recorded the highest average level of contamination with $\mathrm{Cd}$ along the study area $\left(32.80 \mu \mathrm{gg}^{-1} \mathrm{~d}\right.$.w. $)$ representing a hot spot of contamination with this metal for the river ecosystem. Concentration of this metal decreases in a semi-linear pattern throughout the study area but in overall the river environment condition is considered as a heavily polluted with this metal (Table 3). This highly poisonous metal in the environment is considered as an index of industrial pollution (AbdulRaheem et al., 1987).

Table 3: Statistical parameters of exchangeable trace metal concentrations $\left(\mu g^{-1}\right.$ d.w.) of Shatt Al-Arab River sediment, and the environmental condition according to U.S. Environmental Protection Agency.

\begin{tabular}{|l|c|c|c|c|c|c|c|}
\hline \multirow{2}{*}{ Metal } & \multicolumn{2}{|c|}{ Range } & \multirow{2}{*}{ Mean ** } & $\begin{array}{l}\text { Standard } \\
\text { Deviation } \\
\text { (S.D.) }\end{array}$ & $\begin{array}{l}\text { Mean Standard } \\
\text { Error (M.S.E) }\end{array}$ & $\begin{array}{l}\text { Coefficient of } \\
\text { Variation } \\
\text { (C>V\%) }\end{array}$ & $\begin{array}{l}\text { Environm. } \\
\text { Condition }\end{array}$ \\
\cline { 2 - 8 } & Min. & Max. & & \pm 4.33 & 154 & $\begin{array}{l}\text { Heavily } \\
\text { polluted }\end{array}$ \\
\hline Copper $(\mathrm{Cu})$ & 0.00 & 62.38 & 30.12 & 14.80 & \pm 3.31 & 48 & $\begin{array}{c}\text { Moderately } \\
\text { polluted }\end{array}$ \\
\hline Nickel $(\mathrm{Ni})$ & 0.00 & 594.53 & 189.39 & 176.78 & \pm 39.53 & $\begin{array}{c}\text { Heavily } \\
\text { polluted }\end{array}$ \\
\hline Lead $(\mathrm{Pb})$ & 1.20 & 126.32 & 80.47 & 41.94 & \pm 9.38 & $\begin{array}{c}\text { Heavily } \\
\text { polluted }\end{array}$ \\
\hline Zinc $(\mathrm{Zn})$ & 72.23 & 238.98 & 125.09 & 37.21 & \pm 8.32 & 29 & $\begin{array}{c}\text { Moderately } \\
\text { polluted }\end{array}$ \\
\hline
\end{tabular}

* The lower limit is not detected. 
In view of the fact that the dominance of nickel metal in the river ecosystem may be related to the petroleum rich substace (Abaychi and Dou Abal, 1985); Silo station which is located nearby a formerly petroleum refinery and recently as an oil-terminal. It has been recorded the highest average concentration $\left(326.38 \mu \mathrm{gg}^{-1} \mathrm{~d}\right.$.w.). The northern part of Shatt Al-Arab River seem to be heavily polluted by this metal (Table 3 ) reflecting a clear image of contamination by hydrocarbon substances.

Organic detritus may contain of the order of ten times the concentration of lead in the whole sediment (Warren, 1981). Due to the ecosystem state of the northern part of Shatt Al-Arab River which contain a high percentage og organic detritus (0.88-1.25\%) (Table 1); which come from sewage outflow; cause to rising of the level of contamination with trace metal especially with lead. So, the environmental condition of the study area is persumed a heavily polluted by lead according to U.S. Environmental Protection Agency (Table 4). This condition reflects a man-made pollution because of the concentration of lead in sediment is used as an indicator of anthropogenic pollution (AbdulRaheem et al., 1987).

Tabble 4: Criteria used by United States Environmental Protection Agency in defining polluted sediments prior to dredging operations; bulk sediment analysis; ranges in $\left(\mathrm{mg} \mathrm{kg}^{-1} \mathrm{~d} . \mathrm{w}\right.$.). After (Anderlini et al., 1982).

\begin{tabular}{|c|c|c|c|c|}
\hline Parameters & & Non polluted & Moderately polluted & Heavily polluted \\
\hline Cadmium (Cd) & $\mathrm{a}$ & $\mathrm{c}$ & $\mathrm{c}$ & $>6$ \\
\hline Copper $(\mathrm{Cu})$ & $\mathrm{a}$ & $<25$ & $25-50$ & $>50$ \\
\hline Nickel (Ni) & $\mathrm{a}$ & $<20$ & $20-50$ & $>50$ \\
\hline Lead $(\mathrm{Pb})$ & $\mathrm{b}$ & $<40$ & $40-60$ & $>60$ \\
\hline Zinc $(\mathrm{Zn})$ & $\mathrm{b}$ & $<90$ & $90-200$ & $>200$ \\
\hline
\end{tabular}

\section{CONCLUSIONS}

Shatt Al-Arab River considered as a heavily polluted by $\mathrm{Cd}, \mathrm{Ni}$ and $\mathrm{Pb}$, while it was moderately polluted by $\mathrm{Cu}$ and $\mathrm{Zn}$.

The northern part of the study area seem to be a source point for pollution by $\mathrm{Cd}$, indicating an industrial pollution caused by electroplanting works which located nearby this area.

Nickel concentration of the surfacial sediment records the highest value among the other studied metals along the study area. This was reflecting a clear image of hydrocarbon substance contamination.

There are three peaks of lead concentration through the study area, clearing that there is anthropogenic pollution in the river ecosystem.

There are large scales temporal variations of the studied trace metals, reflecting a climbing rate of river pollution especially after the aggression on Iraq.

Stations with higher level of TOC $\%$ have also high level of trace metal concentrations, reflecting a contamination state by sewage effluent. 


\section{REFERENCES}

Abaychi, J.K. and Dou Abal, A.A.Z., 1985. Trace metals in Shatt Al-Arab River, Iraq. Water Research, 19 (13), pp.457-462.

Abaychi, J.K. and Dou Abal, A.A.Z., 1986. Trace element geochemical associations in the Arabian Gulf. Marine pollution Bulletin, 17 (8), pp.353-356.

Abaychi, J.K. and Mustafa, Y.Z., 1988. The Asiatic Clam, Corbicula fluminea: An indicator of trace metal pollution in the Shatt Al-Arab River, Iraq. Environmental Pollution, Series A, 54 (2), pp.109-122.

Abdul Raheem, M.Y.; Habashi, B.; Sadik, M.; Kamel, D. and Yousif, S.M., 1987. Characteristics of Kuwaiti coastal water. Proceeding of the environment and its protection from pollution in the Arabian Gulf country symposium, pp.501-598 (In Arabic).

Albadran, B.N. and Al-Manssory, F.Y., 1999. Distribution patterns of recent sediments in the Shatt Al-Arab River near Basrah City, South Iraq. Marina Mesopotamica, 14 (2), pp.381-394.

Al-Dabbas, M.A. and Hassan, H.A., 1992. Behavior of trace elements in Hor Al-Hammar aqueous sediments, southern Iraq. $10^{\text {th }}$ Geological Congress, Baghdad, pp.28-31, Dec, 1992 (Abstract).

Al-Hashimi, A.H. and Salman, H.H., 1985. Trace metals in the sediments of the northwestern coast of the Arabian Gulf.Marine Pollution Bulletin,16(3),pp.118-120.

Al-Hejuje, M.M., 1999. Distribution of Cobalt, Nickel, Manganese and Iron in the sediment from Al-Ashar and Al-Khandak canals connected with Shatt Al-Arab River, Basrah. Marinea Mesopotamica, 14 (2), pp.365-379.

Al-Imarah, F.J.M. and Al-Khafaji, B.Y., 1998. Effect of industriak effluent upon the levels of trace metals in water and sediments of Shatt Al-Arab River. Basrah J. Science, Series B, 16 (2), pp.27-32.

Al-Imarah, F.J.M.; Al-Khafaji, B.Y. and Mohamed, A.R.M., 1998. Trace metals in waters, sediments and fishes from Northwest Arabian Gulf. Bull. Nat. Inst. Oceanogr. And Fish, A.R.E., 24, pp.403-416.

Al-Imarah, F.J.M., 2001. Levels of trace metals in the water of Shatt Al-Arab River. Marina Mesopotamica, 16 (1), pp.257-265.

Al-Khafaji, B.Y.; Al-Imarah, F.J.M. and Mohamed, A.R.M., 1997. Trace metals in water, sediments and green black Mallet (Liza Subviridis, Valencielles, 1836) of the Shatt Al-Arab Estuary, NW Arabian Gulf. Marina Mesopotamica, 12 (1), pp.7-23.

Al-Manssory, S.N. and Salman, H.H., 1989. Heavy metals distribution in Khor Al-Zubair sediments, NW Arabian Gulf. Marina Mesopotamica, 4 (2), pp.309-318.

Anderlini,V.C.; Mohammed, O.S.; Zarba, M.A. and Omar, N., 1982. Assessment of trace metal pollution in Kuwait. Vol.1 of the final report of the trace element and bacterial pollutants project, EES-31A.KISR, $212 \mathrm{p}$.

Anderlini,V.C.; Mohammed,O.S.; Zarba, M.A.; Awayes, R.A. and Al-Jalili, R., 1986. An assessment of trace Mattel pollution in Kuwait marine environment. Proceedings of the first Arabian Gulf Conference on environment and pullution, Kuwait, 1982, pp.133-156.

Dean, J.G.; Bosqui, F.L. and Lanuette, H., 1972. Remove heavy metals from wastewater. Environmental Science and Technology, 6, pp.518-522. 
Folk, R.L., 1974. Petrology of sedimentary rocks. Hemphill Pub. Co., 182p.

Folk, R.L. and Ward, W.C., 1957. Brazos river bar: a study in the significance of grain size parameters. J. Sed. Pet., 27 (1), pp.3-26.

Forstner, U. and Muller, H., 1973. Heavy metal accumulation in river sediments: A response to environmental pollution. Geoforum, 14, pp.53-61.

Forstner, U. and Wittman, G.T.W., 1979. Metal pollution in the aquatic environment. Spinger Verlag.

Jackson, M.L., 1958. Soil chemical analysis. Prentice Hall Pub., New York.

Johansson, K., 1989. Metals in sediment of lakes in Northern Sweden. Water, Air and Soil Pollution, 47, pp.441-455.

Ledin, A.; Pettersson, C. and Allard, B., 1989. Background concentration ranges of heavy metals in Swedish ground waters from crystalline rocks: A review. Water, Air and Soil Pollution, 47, pp.419-429.

Mustafa, Y.Z. and Al-Saad, H.T., 1995. Seasonal variations of trace elements in aquatic vascular plants from Al-Hammr Marsh, Iraq. Marina Mesopotamica, 10 (2), pp.321329.

Page, E.R.; Miller, R.H. and Kenny, D.R. (eds.), 1982. Method of soil analysis, part 2, $2^{\text {nd }}$ edition. Agronomy 9, Madison, Wisconson.

Radwan, S.; Kowalik, W. and Kornijow, R., 1990. Accumulation of heavy metals in lake ecosystem. The Science of the total environment, 96, pp.121-129.

Saleh, A.A., 1982. Hydrochemistry and Geochemistry of Tigris River and possible pollution from Baghdad till Qurna. M.Sc. Thesis, College of Science, Baghdad University, 197p. (In Arabic).

Warren, L.J., 1981. Contamination of sediments by lead, zinc and cadmium: A review. Environmental Pollution, Series B, 2, pp.401-436. 